\title{
A Quest for a Sustainable Alternative Wood Species to Produce World Class Clarinets
}

\author{
Lívia Cipriano Almeida Barros, ${ }^{\mathrm{a} *}$ Eduardo Luiz Longui, ${ }^{\mathrm{b}}$ and Lech Muszynski ${ }^{\mathrm{c}}$
}

\begin{abstract}
Clarinets are made with a variety of materials, e.g., plastic, graphite, porcelain, or even metal. However, the most commonly used material to make clarinets is wood. Today, African granadilla or African blackwood (Dalbergia melanoxylon) is the most popular and most widely used species by leading international companies in terms of clarinet production, because of its high density, color, fine texture, and exceptional durability. This species is also used to manufacture flutes, oboes, and bagpipes, making African blackwood one of the most valuable tree species in the world. However, the focus on the usage of a single species puts considerable pressure on a rare and endangered wood species. Therefore, this work aims to identify viable alternatives to African blackwood in terms of manufacturing clarinets as well as providing a similar combination of instrument characteristics that musicians and companies believe contribute to the value of the instrument, e.g., acoustics, aesthetics, and price.
\end{abstract}

Keywords: Woodwind instruments; Music; Endangered species; Tropical wood; African blackwood

Contact information: a: Universidade Federal de São Carlos, Rodovia João Leme dos Santos, Sorocaba SP 18052-780 Brazil; b: Instituto Florestal, R. do Horto, 931 - Horto Florestal, São Paulo - SP 02377-010 Brazil; c: Oregon State University, Corvallis, OR 97331 USA;

*Corresponding author: livia_cipriano@hotmail.com

\section{INTRODUCTION}

The clarinet is a member of the woodwind family and is one of the most popular musical instruments in the world. The earliest clarinet was created by Johann Christoph Denner during the 1700s in Germany. It was made entirely with wood, except for the metal keys (Hoeprich 2008).

Contemporary clarinets consist of five parts: the mouthpiece, barrel, left-hand section, right-hand section, and bell (as shown in Fig. 1). The most common key system found in clarinets today is the Boehm system clarinet, which was developed between 1839 and 1843 by Hyacinthe Klosé and Auguste Buffet. This key system is played by the majority of musicians in the world (Hoeprich 2008).

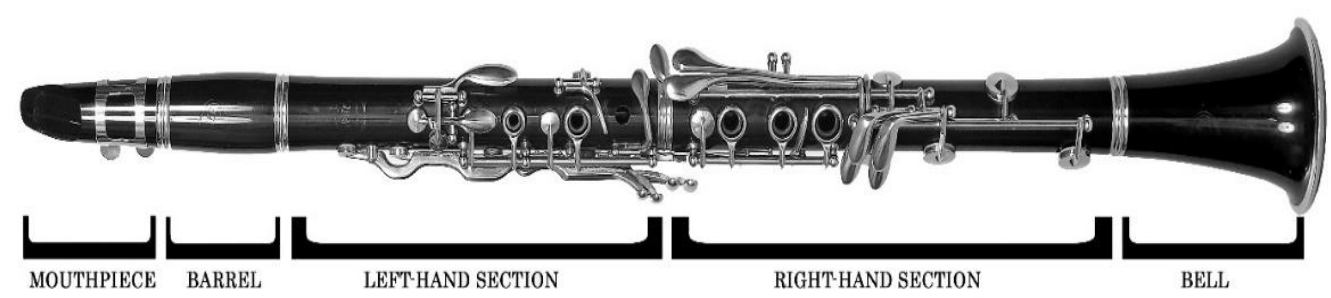

Fig. 1. Parts of the clarinet: the mouthpiece, barrel, left-hand section, right-hand section, and bell 
While contemporary clarinets are also made with a variety of materials other than wood, e.g., plastic (in various colors), graphite, porcelain, ebonite, hard rubber, or even metal, wood remains the most commonly used material, and African blackwood (Dalbergia melanoxylon Guill. and Perr. a species of the Fabaceae family), is the most popular wood species for clarinet-making. African blackwood started to dominate the clarinet market at the beginning of the $20^{\text {th }}$ century when the commercial export of this species began from Mozambique and Tanzania (Jenkins et al. 2002). Other species are used, but on a much smaller scale.

Some characteristics that make African blackwood the favorite species for making clarinets is the black color of the heartwood, its wood density, its toughness, and the durability of the heartwood (Lincoln 1986). The heartwood of this species has high durability against both termite and fungal attacks (Nakai and Yoshimura 2020) and high durability in terms of dimensional stability, characteristic required for clarinets to resist to high level of moisture and, therefore, to keep the clarinet quality (Wegst 2006). According to Lincoln (1986), "its oiliness, resistance to climate change, and ability to take an exceptional finish makes it preferable to ebony for making high-quality clarinets."

African Blackwood, is also known as Grenadilla, Mpingo, Mozambique Ebony, and Pau Preto. According to Barstow (2020), this species is found in: Angola, Botswana, Burkina Faso, Cameroon, Central African Republic, Chad, The Democratic Republic of the Congo, Côte d'Ivoire, Eritrea, Eswatini, Ethiopia, Kenya, Malawi, Mali, Mauritania, Mozambique, Namibia (Caprivi Strip), Nigeria, Senegal, South Africa (Limpopo Province, Mpumalanga), South Sudan, Sudan, Tanzania, Togo, Uganda, Zambia, and Zimbabwe (as shown in Fig. 2). However, it is only possible to find enough trees of sufficiently harvestable size in East Africa (Ball 2004). Specifically, Mozambique and southern Tanzania are the two places where most African Blackwood comes from. Besides its economic value, this species has cultural importance in Tanzania because it is considered a national tree (Kenyon 2011).

Countries, in which

Dalbergia melanoxylon is

Present

Harvested

Commercially harvested and exported
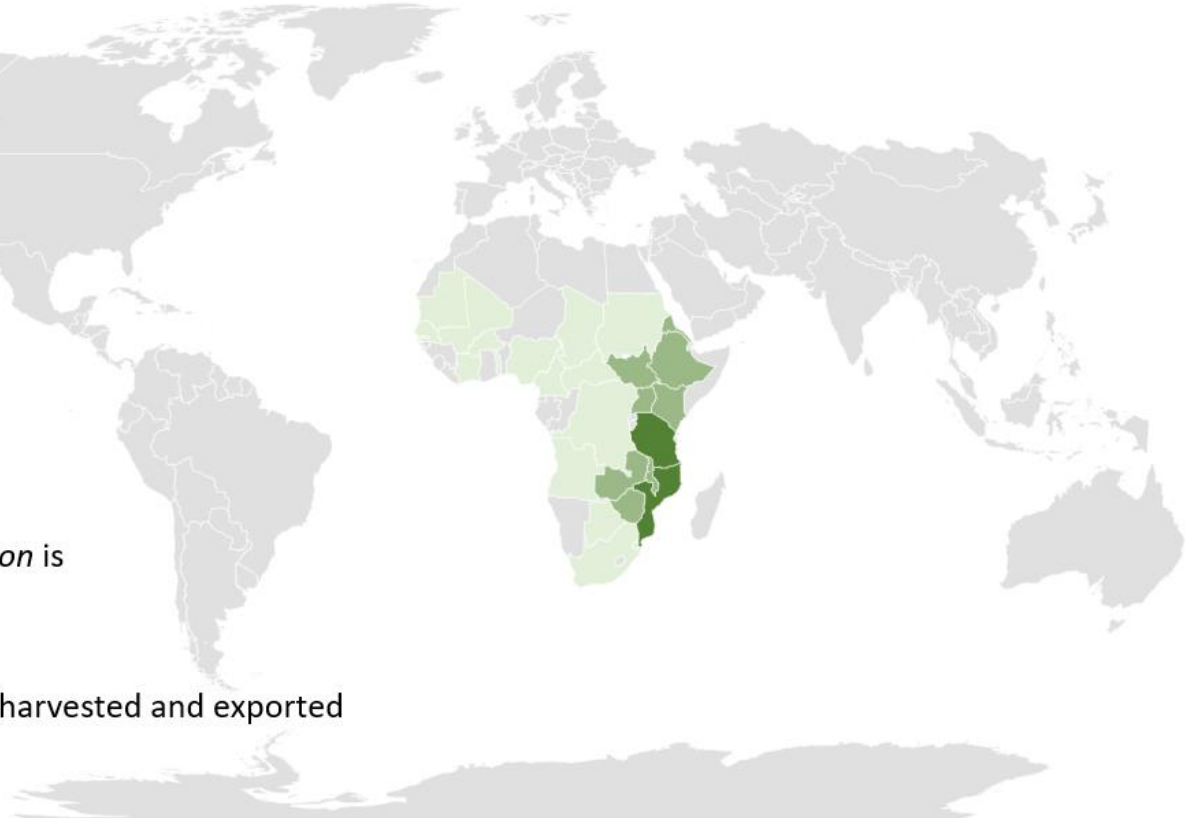

Fig. 2. Distribution of African Blackwood across the world (Barstow 2020; Ball 2004) 
Apart from clarinets, African Blackwood is also used to make flutes, oboes, and bagpipes, making it one of the most prized trees in the world. This species can have an export value as high as US\$ 18000 per cubic meter. However, the use of this particular species to make clarinets puts considerable pressure on a limited resource. According to Jenkins et al. (2002), every year approximately 7500 to 20000 African Blackwood trees are harvested to produce musical instruments. In 2004 and 2005, it is estimated that as much as $96 \%$ of the timber logged in Tanzania was illegally harvested (Harrison 2008). It is estimated that 20,000 to 25,000 clarinets are sold annually in the United Kingdom and that most of these are made from African Blackwood. Currently, global clarinet production is dominated by a small number of manufacturers that produce over 65,000 African Blackwood clarinets and oboes annually (Jenkins et al. 2002).

The manufacturing of clarinets demands high quality-part of wood without any defects or imperfections. These requirements make the production of clarinets extraordinarily wasteful because many trees are harvested to make only a few clarinets, making this an unsustainable process. Each clarinet requires billets totaling a volume of $0.0015 \mathrm{~m}^{3}$. However, the waste from hidden defects can run as high as $25 \%$, increasing the volume of billets used to manufacture each instrument to up to $0.0019 \mathrm{~m}^{3}$. Therefore, the manufacturing of clarinets and oboes likely accounts for anywhere between $120 \mathrm{~m}^{3}$ and $190 \mathrm{~m}^{3}$ of exported billets annually (Jenkins et al. 2002). Instrument makers lose some of their perfect African Blackwood pieces during the machining process at the factory; it is estimated that up to $20 \%$ of their workpieces are lost (African Blackwood Conservation Project 2018).

Furthermore, African Blackwood plantations are not economically viable due to long rotation time (Gregory et al. 1999). A harvestable-sized tree has a minimum age of at least 80 years old, since this species grows very slowly (Jenkins et al. 2002) and a minimum diameter at breast height (DBH) over 24-cm, regulated in Tanzania (Nakai 2020). Regional experts do not believe current exploitation levels are sustainable, although this information needs to be verified (Ball 2004). This means that the raw timber materials for the most valued woodwind instruments comes from an unsustainable source. Therefore, it is necessary to preserve this tree and manage a sustainable harvest to keep African Blackwood as an option for commercial timber. Right now, African Blackwood is not threatened with biological extinction, but illegal harvesting, deforestation, and unsatisfactory fire management could make it commercially out of reach in the near future (Ball 2004). Consequently, African Blackwood has already disappeared from parts of its former range in Eastern Africa, and the rate of deforestation is increasing. Commercial stocks of African Blackwood have been exhausted in various parts of Tanzania (Jenkins et al. 2002). In addition, this species has already been recorded as rare in Mozambique through intensive exploitation. According to Scott Paul from Greenpeace, "If we lose some of these species, we are going to lose the sound" (Perry 2008).

Many organizations are working on the conservation of this species: Daraja Music Initiative, also known as "Clarinets for Conservation", African Blackwood Conservation Project, Mpingo Conservation \& Development Initiative (MCDI), and Fauna \& Flora International, as well as the Tanzanian government (Ball 2004; Palmer 2016; Nakai et al. 2019). Most of these organizations work to support rural communities to sustainably manage their forests by training communities to responsibly harvest timber and connect communities and buyers.

Therefore, it is necessary to identify viable alternatives to this rare and endangered wood species for the manufacturing of clarinets. In order to be successful, the search for 
sustainable alternatives to African Blackwood to be used for manufacturing of clarinets must carefully consider the physical, mechanical, and aesthetic properties of the replacement, as well as the readiness of the music local community to accept it.

\section{Research Aims}

The aim of this article is to identify alternative wood species used to produce clarinets and to determine the instrument characteristics that musicians and companies believe contribute to their value, e.g., quality sound, aesthetics, and price.

\section{EXPERIMENTAL}

\section{Methods}

The information presented in this study was collected from three types of sources: literature review, direct interviews with experts in the field, and online surveys distributed via email.

\section{Literature review}

In the first stage of the literature review, specialized journals and books focused on topics related to musical instruments were identified through a university library network (https://search.library.oregonstate.edu/). This review turned up more than 60 articles and 20 books about musical instruments in general and about clarinets specifically. The general topics reviewed included clarinet history, clarinet manufacturers, the variety and innovations about materials used to make clarinets, the physical and mechanical properties of the utilized wood species, and the physics of woodwind instruments.

\section{Interviews}

Interviews with 47 experts in the field were conducted via email (40), telephone (3), and personal contact (4).

The institutions contacted included clarinet manufacturers, musical instrument museums, and conservatories. Their locations are listed in Table 1. Manufacturers were contacted in order to identify the wood species and other materials used to make modern clarinets as well as the physical and mechanical properties of the wood species that companies believe are important for clarinet production. Museums were consulted in order to collect historical information about clarinets. Music schools and conservatories were contacted to gather general information about clarinets played by professional musicians and to connect with clarinetists, both professors and students, who were then targeted with surveys.

\section{Online survey}

Clarinet teachers, clarinet renovators, repair shop owners, clarinetists, and members of clarinet associations were contacted to answer an online survey sent via email. The list of invited individuals and institutions is presented in Table 2. The objective of this survey was to gather specific information about clarinets not otherwise found in the reviewed literature, e.g., the opinions and knowledge of musicians, manufacturers, and repair shop owners on clarinets and the materials they are made of. In addition, repair shop owners were asked about the use of broken clarinet pieces.

The questionnaire was implemented by using a free version of an online survey 
service (Survey Monkey), available at https://www.surveymonkey.com/s/FS9L7CD. The questions were related to durability, factors associated with clarinet quality and depreciation, as well as types of wear or damage that make clarinets permanently unusable. An additional point addressed was the importance of the brand, aesthetics, quality, tradition, and price in the choice of instrument, as well as brand preference. The list of questions is presented in Table 3.

Table 1. List of Institutions Contacted for Interviews and their Location

\begin{tabular}{|c|c|c|}
\hline & Institutions Contacted & Location \\
\hline \multirow{10}{*}{$\begin{array}{c}\text { Clarinet } \\
\text { Manufacturers }\end{array}$} & Buffet Crampon & Paris, France \\
\hline & Chadash Clarinet & New York, USA \\
\hline & Devon \& Burgani & Diadema, Brazil \\
\hline & Hand Made Clarinets - L. Rossi & Santiago, Chile \\
\hline & Hanson - England & $\begin{array}{l}\text { Hanson Clarinet Company - } \\
\text { West Yorkshire, England }\end{array}$ \\
\hline & Henri Selmer Paris & Paris, France \\
\hline & Jupiter & Mount Juliet, Tennessee, USA \\
\hline & Leblanc & Wisconsin, USA \\
\hline & Selmer & Elkhart, Indiana, USA \\
\hline & Yamaha & $\begin{array}{c}\text { Yamaha Corporation of } \\
\text { America - California, USA }\end{array}$ \\
\hline \multirow{5}{*}{$\begin{array}{c}\text { Musical } \\
\text { Instruments } \\
\text { Museums }\end{array}$} & $\begin{array}{c}\text { European Traditional Instruments } \\
\text { The Grassi Museum }\end{array}$ & $\begin{array}{l}\text { Brussels - Belgium } \\
\text { Leipzig, Germany }\end{array}$ \\
\hline & Metropolitan Museum of Art & New York, New York \\
\hline & Musical Instrument Museum & Phoenix, Arizona \\
\hline & Musical Instruments Museum & Musical Instruments Museum \\
\hline & $\begin{array}{c}\text { The Orpheon Foundation - Museum of } \\
\text { Historical Musical Instruments }\end{array}$ & Vienna, Austria \\
\hline \multirow{3}{*}{ Conservatories } & $\begin{array}{l}\text { Conservatoire National Superieur de } \\
\text { Musique et de Danse de Paris }\end{array}$ & Paris, France \\
\hline & $\begin{array}{c}\text { Conservatório Dramático e Musical Dr. } \\
\text { Carlos de Campos de Tatuí }\end{array}$ & Tatuí, Brazil \\
\hline & $\begin{array}{l}\text { The Boston Conservatory, Minnesota } \\
\text { State College - Southeast Technica }\end{array}$ & Minnesota, USA \\
\hline
\end{tabular}

Table 2. List of Institutions Contacted for the Online Survey and their Location

\begin{tabular}{|c|c|c|}
\hline \multirow{4}{*}{ Associations } & Institutions Contacted & Location \\
\hline \multirow{4}{*}{ Repair Shops } & Deutschen Klarinetten-Gesellschaft & $\begin{array}{c}\text { www.deutsche-klarinetten- } \\
\text { gesellschaft.de }\end{array}$ \\
\cline { 2 - 3 } & International Clarinet Association & http://clarinet.org/ \\
\cline { 2 - 3 } & World Clarinet Alliance & http://www.wka-clarinet.org/ \\
\hline & American Music & Lynnwood, Washington \\
\cline { 2 - 3 } & Beacock Music & Vancouver, Washington \\
\cline { 2 - 3 } & Gracewinds & Corvallis, Oregon \\
\cline { 2 - 3 } & Guitar Center & Portland, Oregon \\
\cline { 2 - 3 } & Music \& Arts & Redmond, Washington \\
\cline { 2 - 3 } & Portland Music Co. 'On Broadway' & Portland, Oregon \\
\cline { 2 - 3 } & Ted Brown Music & Washington \\
\hline
\end{tabular}


Table 3. Questionnaire

\begin{tabular}{|c|c|}
\hline \multicolumn{2}{|r|}{ Questions } \\
\hline 1 & $\begin{array}{l}\text { What do you believe the typical service life of a clarinet to be? (years) What is the oldest } \\
\text { clarinet that you ever played or found in your experience? }\end{array}$ \\
\hline 2 & List the factors you believe to contribute to clarinet depreciation. \\
\hline 3 & $\begin{array}{l}\text { List the factors that will make a clarinet permanently unusable. Check all answers that } \\
\text { apply. } \\
\text { - When it falls and breaks. } \\
\text { - When it dries out excessively. } \\
\text { - Keys wear } \\
\text { - Other (please specify) }\end{array}$ \\
\hline 4 & $\begin{array}{l}\text { Which is your favorite brand? } \\
\text { - } \quad \text { Buffet Crampon } \\
\text { - } \quad \text { Chadash Clarinet } \\
\text { - } \quad \text { Hevon \& Burgani } \\
\text { - Hanson - England } \\
\text { - Henri Selmer Paris } \\
\text { - Jupiter } \\
\text { - Leblanc } \\
\text { - Selmer } \\
\text { - } \quad \text { Yamaha }\end{array}$ \\
\hline 5 & $\begin{array}{l}\text { If you know which wood species are used to make the clarinet, list them here (Please } \\
\text { write the scientific name) }\end{array}$ \\
\hline 6 & $\begin{array}{l}\text { How important do you believe the following motives to be for musicians selecting a } \\
\text { Clarinet. Most important }-5 \text { and less important - } 0 \\
\text { - Brand } \\
\text { - Esthetics } \\
\text { - Quality (sound) } \\
\text { - } \quad \text { Pradition } \\
\text { - } \quad \text { Others: Please specify }\end{array}$ \\
\hline 7 & $\begin{array}{l}\text { Describe characteristics that, in your opinion, contribute to the musical quality of a } \\
\text { clarinet. }\end{array}$ \\
\hline 8 & $\begin{array}{l}\text { How familiar are you with clarinet manufacturing techniques? } \\
\text { - Not familiar at all } \\
\text { - Somewhat familiar (I know the principal steps of the manufacturing process) } \\
\text { - } \quad \text { I am an expert (e.g. I make or repair clarinets myself) }\end{array}$ \\
\hline 9 & $\begin{array}{l}\text { Are you familiar with the clarinet history? Its manufacturers and materials used in the } \\
\text { past? } \\
\text { - Not familiar at all } \\
\text { - Somewhat familiar } \\
\text { - Very familiar (I read books and/or articles about the topic) } \\
\text { - I am an expert (e.g. academic, museum curator, or writer on this topic) }\end{array}$ \\
\hline 10 & Do you know what happens with broken or abandoned clarinets? \\
\hline
\end{tabular}

The online surveys were sent to 200 people, including musicians, members of associations, music teachers, and repair shop owners. The response rate was calculated using the formula shown in Eq. 1, 


$$
\text { Response rate }=\frac{\text { Responses received }}{\text { Surveys sent }}
$$

\section{Information analysis}

The information collected from the three different sources (literature review, interviews, and online surveys) was processed and combined to provide a list of sustainable alternative wood species to produce clarinets.

\section{RESULTS AND DISCUSSION}

The results include data about the characteristics of clarinets that musicians and manufacturers believe contribute to their value, such as sound quality, aesthetics, and price. These data also include information about alternative species used to make clarinets and how their key characteristics compare to African Blackwood.

The results from the three different sources (literature review, interviews, and online surveys) are presented separately.

\section{Literature Review}

Based on the literature review, some conclusions could be made about the variety and innovations of materials used to manufacture clarinets. Considering the variety of materials used to make clarinets, African Blackwood is the most used species for clarinet production, although other species are used on a smaller scale. According to Hoeprich (2008), "Occasionally ebony wood (Diospyros melanoxylon) is used, and in the past, cocus (Byra ebenus), boxwood (Buxus sempervirens) and various types of rosewood (Dalbergia nigra) have been popular [...] Ebonite, developed to have a density similar to that granadilla [Dalbergia melanoxylon], is cheaper and unlikely to crack". According to Wegst (2008), besides African Blackwood (Dalbergia melanoxylon), Brazilian rosewood (Dalbergia nigra) and Macassar ebony (Diospyros celebica) are also preferred for clarinet production. These woods are used because of their high density, fine grain, and good dimensional stability under the influence of moisture.

One clarinet manufacturer innovated its clarinet production process by starting a Green-Line project, the objective of which was to limit the use of African Blackwood in their clarinets and oboes. According to Hascoet (2020), this company developed a patented process for fabricating instruments with a wood plastic composite, in which wood powder from this species, generated as waste from production of solid wood instruments, is combined with carbon fiber (95\% to 5\% ratio, respectively). While this production method still uses African Blackwood to make the Green-Line clarinets, it results in less "waste" of overall wood material than the regular process.

There are many clarinet companies around the world, and some of them were contacted in this research. According to an online compilation, the 30 best-known companies are listed in Table 4 (Ranker 2018). 
Table 4. List of Clarinet Companies

\begin{tabular}{|c|c|c|c|c|c|}
\hline ID & Companies & ID & Companies & ID & Companies \\
\hline 1 & Buffet Crampon & 11 & Devon \& Burgani & 21 & Luis Rossi \\
\hline 2 & Leitner and Kraus & 12 & Wolfgang Dietz & 22 & Amati-Denak \\
\hline 3 & Yamaha Corporation & 13 & Schreiber & 23 & Leblanc \\
\hline 4 & Morrie Backun & 14 & Jupiter & 24 & Palatino \\
\hline 5 & Herbert Wurlitzer Clarinets & 15 & Stephen Fox & 25 & Peter Eaton \\
\hline 6 & Hakam Din and Sons & 16 & Hammerschmidt & 26 & Mirage \\
\hline 7 & F. Arthur Uebel & 17 & Gerold Klarinetten & 27 & Bay \\
\hline 8 & Hanson Clarinet Company & 18 & E. K. Blessing & 28 & Selmer \\
\hline 9 & Schwenk Und Seggelke & 19 & L. A. Ripamonti & 29 & Etude \\
\hline 10 & Howarth of London & 20 & Chadash Clarinet & 30 & Patricola \\
\hline \multicolumn{2}{|r|}{ Note: According to Ranker (2018) } & & \\
\hline
\end{tabular}

\section{Interview}

Interviews provided information about the history of clarinets and the materials used to make a clarinet. According to the interview with Palmer (2015), a museum educator at the MIM (Musical Instruments Museum), almost all clarinet makers used boxwood (Buxus sempervirens) in the past. However, during the late $1800 \mathrm{~s}$, clarinet makers started to use African Blackwood (Dalbergia melanoxylon), because its durability and tone quality were much better than boxwood. In addition, during this time, clarinet makers were adding additional keys and tone holes; consequently, they needed a stronger wood to support the new weight of the clarinet. Currently, other species are used to make clarinets, e.g., Honduran rosewood (Dalbergia stevensonii). However, its density, one of the most important wood properties in terms of quality of the tone, is lower than that of African Blackwood (Rossi 2015).

Considering the physical and mechanical properties of a wood species that manufacturers believe are important for clarinet production, Jousserand (2015), a research engineer at the Buffet Group, states that the dimensional stability, especially in the tangential and radial direction, is one of the most important properties of clarinets. Additional important properties include impermeability to air and supporting the weight of the keywork. Since African Blackwood has all these characteristics, it remains the most widely used species to make the highest quality modern clarinets.

\section{Online Survey}

The online survey was sent to 200 individuals, of which 73 responses were received by November 08, 2015. Therefore, the response rate was calculated using Eq. 1, and found to be $36.5 \%$, which was considered satisfactory.

The first question involved the service life of a clarinet. The responses ranged widely: respondents believing that the service life of a clarinet is at least 3 years but can be as long as 200 years. The average of all responses was 100 years. Some responses were 
more nuanced; one respondent replied "I have played on a 50 years old clarinet. Still worked, but not the greatest sound". It is reasonable to assume that these results depend on the usage, clarinet care, properties of the wood species, and manufacturing techniques.

The belief that clarinets can be played for as long as 200 years, as expressed by some respondents, is contradicted by Jenkins et al. (2002), who reported that professional quality clarinets may maintain their high performance for approximately six years. The reason for this is that the moist spray blown inside the instrument by the player causes the internal surface to become wet. Under normal circumstances, wetting would cause the wood to swell, but the internal surface of the clarinet is restricted, and the suppressed swelling generates stress that may lead to damage. With time, the repeated wetting of the internal surface of the instrument also deteriorates the quality of the wood, even if extremely careful cleaning and conservation procedures are applied. This is different from some stringed instruments, e.g., violins, which, given the appropriate maintenance, could be played for hundreds of years without appreciable loss in quality. Even if the number of musicians remains the same, the relatively short life of the clarinet guarantees a steady demand for replacement instruments. Despite the relative short life, wood materials are still necessary for high quality clarinet manufacturing. Therefore, the alternative wood species with both high durability and sustainability is highly required in the future.

Table 5 shows the factors believed to contribute to clarinet depreciation. The principal factor is damage to the body of the clarinet. One factor that contributes to clarinet depreciation, according to the survey, is exposure to temperature extremes, i.e., rain and dry weather, and human saliva, which will increase the amount of moisture present in the clarinet. Additional factors addressed were damage to the keys due intense usage, inadequate care and maintenance, wearing down of the tone holes, and not being played for a long period of time.

Table 5. Factors that Contribute to Clarinet Depreciation

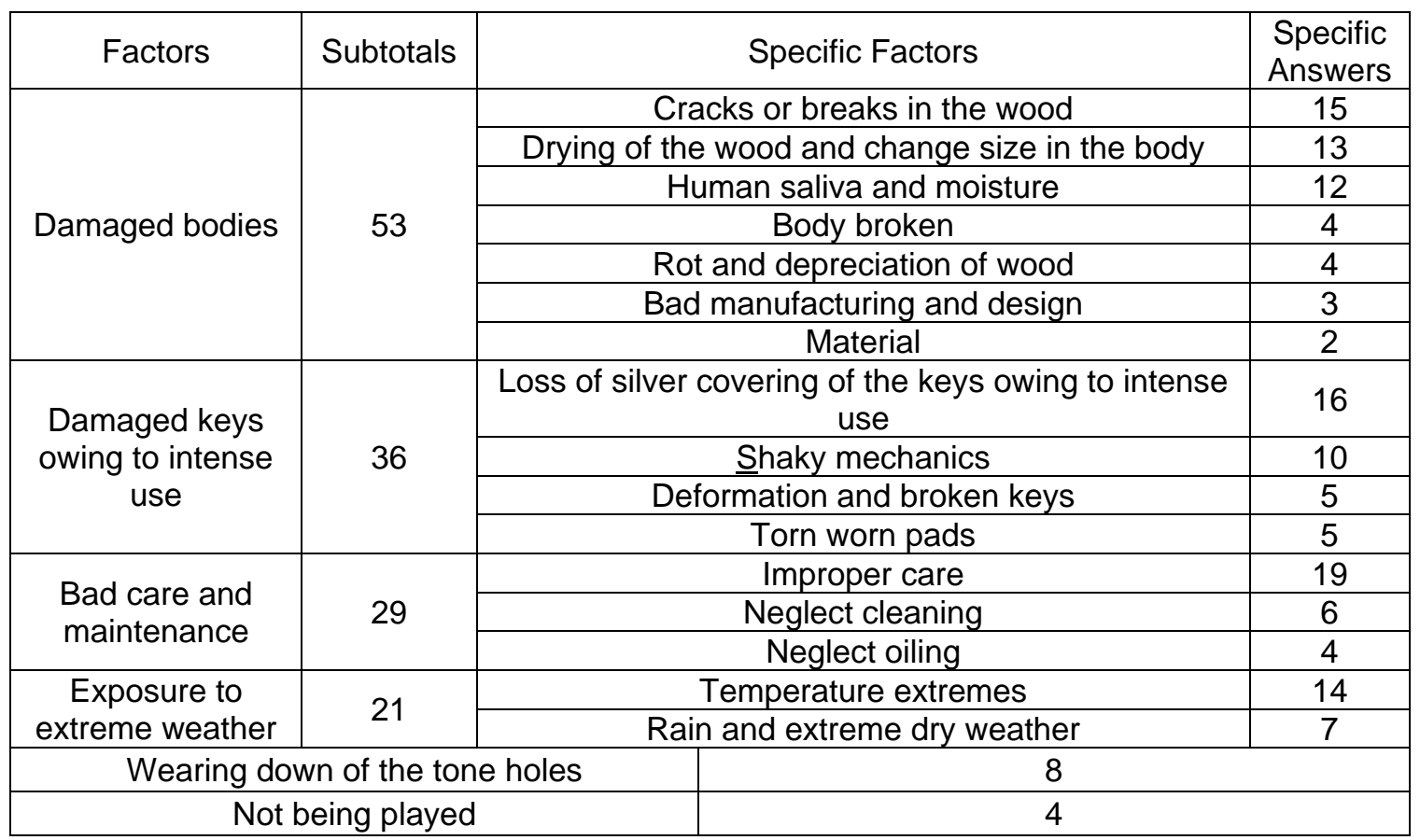


According to Jenkins et al. (2002), wood deformation or cracking, as well as keyhole breakage, is produced by stresses between the inside and the outside of the instrument. This stress is due to the fact that when blown into, the air inside the clarinet varies in humidity and temperature; for this reason, the material needs to constantly resist the stresses of playing. Clarinet maintenance is especially important to avoid cracks or breaks in the wood or the breakage of the keys. Factors that are believed to make a clarinet permanently unusable are presented in Table 6. The most popular responses are serious mechanical damage and excessive dryness.

Table 6. Factors That Will Make a Clarinet Permanently Unusable

\begin{tabular}{|c|c|}
\hline Factors & Answers \\
\hline When it falls and breaks - mechanical damage & 41 \\
\hline When it dries out excessively. & 29 \\
\hline Keys wear out, crooked or broken keys & 21 \\
\hline Strong and large cracks in the wood & 10 \\
\hline Changes in bore size (deformation) & 9 \\
\hline Break of bore & 1 \\
\hline Warping or rotting of the wood & 1 \\
\hline
\end{tabular}

Clarinets are permanently unusable if they fall and break, causing mechanical damage. In addition, if the wood becomes excessively dry, it could result in changes in bore size, which causes permanent deformation and crooked keys. The keys could wear out because of continuous usage. Large cracks in the wood cannot be repaired. In addition, warping or rotting of the wood can also make the clarinet unworkable. Favorite clarinet brands named by the survey respondents are listed in Table 7. Most respondents selected Buffet Crampon, a French company which has produced clarinets since 1825.

Table 7. Favorite Clarinet Brands of the Participants

\begin{tabular}{|c|c|}
\hline Manufacturers & Answers \\
\hline Buffet Crampon & 33 \\
\hline Schwenk \& Seggelke & 7 \\
\hline Selmer & 7 \\
\hline Yamaha & 7 \\
\hline Henri Selmer Paris & 4 \\
\hline Leitner \& Kraus & 4 \\
\hline Wurlitzer & 4 \\
\hline Ridenour (Lyrique) & 3 \\
\hline Backun & 2 \\
\hline Buffet Green Line & 2 \\
\hline F.A. Uebel - Superior & 2 \\
\hline Fratelli Patricola & 2 \\
\hline Hammerschmidt & 2 \\
\hline Leblanc & 2 \\
\hline Wolfgang Dietz & 2 \\
\hline Chadash Clarinet & 1 \\
\hline Hanson - England & 1 \\
\hline Howarth - England & 1 \\
\hline Hueying & 1 \\
\hline Hufnagel (German System) & 1 \\
\hline Karl Friedrich Todt & 1 \\
\hline Schreiber & 1 \\
\hline
\end{tabular}


Considering the survey answers, the favorite clarinet manufacturing company was Buffet Crampon. A small number of large manufacturers monopolize the production of woodwind instruments, producing several thousand instruments annually. There are also a number of small-scale manufacturers that make a few hundred instruments annually. According to Jenkins et al. (2002), there are four global large manufacturers of clarinets and oboes, with the largest manufacturer producing just over 30000 wooden clarinets annually. On the basis of wood use, the second largest manufacturer probably produces approximately two thirds of this number of clarinets and oboes combined."

Responses concerned with the importance of brand name/reputation, aesthetics, musical quality (tone), tradition, and price for selecting a clarinet are presented in Table 8 . For musicians, music quality and brand are very important, while price is named as "important", and tradition and aesthetics are "somewhat important."

Table 8. Reasons for Selecting a Clarinet in Order of Importance

\begin{tabular}{|c|c|c|c|c|c|}
\hline Level of Importance & Musical Quality & Brand & Tradition & Aesthetics & Price \\
\hline Very Important & 70 & 25 & 11 & 10 & 9 \\
\hline Important & 1 & 21 & 18 & 20 & 30 \\
\hline Somewhat Important & 1 & 21 & 37 & 37 & 27 \\
\hline Not Important & 1 & 6 & 7 & 6 & 7 \\
\hline
\end{tabular}

Therefore, musical quality and brand are the most important aspects compared to aesthetics, tradition, and price, which are less important to musicians. For this reason, musicians tend to buy a musical instrument based on experience, i.e., trying the instrument before buying, according to survey responses. Despite price and aesthetics be "somewhat important" for musicians, they are still a determining factor for selecting a clarinet. Aesthetics, more specifically, the body color and the keys material (nickel, silver or gold), are essential for the acceptance by musicians. It is known that black is the traditional color of wood preferred by musicians (Slooten and Souza 1993), and nickel keys is the material used in more affordable clarinets.

Table 9. Characteristics That Contribute to the Musical Quality of a Clarinet

\begin{tabular}{|c|c|}
\hline Characteristics That Contribute to the Musical Quality of a Clarinet & Responses \\
\hline Resonance intonation & 18 \\
\hline Tone quality (timbre and sonority) & 17 \\
\hline Resistance of keys and keyword design & 16 \\
\hline Material & 14 \\
\hline Good mouthpiece & 11 \\
\hline Simple and accurate bore shape and size & 10 \\
\hline Easy response flexibility in sound & 6 \\
\hline Equality of sound in all registers and ability to seal completely & 5 \\
\hline Good craftsmanship (manufacturing) & 5 \\
\hline Reed & 5 \\
\hline Wood density & 4 \\
\hline Good pitch & 3 \\
\hline Right balance of the harmonics & 3 \\
\hline Tightness of pads (material also) & 2 \\
\hline
\end{tabular}


Survey responses concerned with the characteristics that contribute to the musical quality of a clarinet are presented in Table 9. The characteristics selected most often are resonance intonation, tone quality, the resistance of the keys and keyboard design, as well as the material used in the clarinet.

Responses about the level of familiarity with clarinet manufacturing techniques are presented in Table 10. Most respondents claimed to be somewhat familiar with the principal steps of the manufacturing process of clarinets. That should not be surprising since respondents targeted by the survey were musicians, clarinet teachers, clarinet repair professionals, and members of clarinet associations.

Table 10. Familiarity of Respondents with Clarinet Manufacturing Techniques

\begin{tabular}{|c|c|}
\hline Answer Choices & Responses (\%) \\
\hline Somewhat familiar (I know the principal steps of the manufacturing process) & 60.27 \\
\hline Very familiar (I know specific tools and/or techniques) & 23.29 \\
\hline Not familiar at all & 8.22 \\
\hline I am an expert, i.e., I make or repair clarinets myself & 6.85 \\
\hline
\end{tabular}

The familiarity of the respondents with clarinet history, manufacturers, and materials used in the past are presented in Table 11. Most respondents claim that they are very familiar with clarinet history, clarinet companies, and the materials. They pointed to books and articles about these topics as the source of their information.

Table 11. Familiarity of Respondents with Clarinet History, Manufacturers, and Materials Used in the Past

\begin{tabular}{|c|c|}
\hline Answer choices & Responses (\%) \\
\hline Very familiar (I read books and/or articles about the topic) & 60.27 \\
\hline Somewhat familiar & 26.03 \\
\hline I am an expert, i.e., academic, museum curator, or writer on this topic & 9.59 \\
\hline Not familiar at all & 4.11 \\
\hline
\end{tabular}

In conclusion, it was possible to categorize the respondents by their knowledge about wood species used to make the clarinet, manufacturing techniques, and clarinet history. These two questions are especially important because the confidence in the outcome of the survey is based on the fact that the targeted population was composed of professional musicians, clarinet teachers, clarinet association members, and repair professionals, most of whom declared their familiarity with clarinet manufacturing techniques, clarinet history, clarinet manufacturers, and materials used in clarinet production.

The last survey question was about the final disposition of broken or abandoned clarinets. The responses revealed a variety of ways broken clarinets are utilized. If the amount of damage is low, they can be sent to instrument donation centers or musical instrument museums. Permanently damaged clarinets can be sent to repair shops where they can be used for spare parts or used as decoration, e.g., lamps or chandeliers, or even pulverized to a fine powder for use in repairs and other applications, e.g., the green line of reconstituted wood-plastic clarinets produced by the Buffet Crampon group. Finally, some 
broken clarinets are discarded and sent to a landfill, as confirmed by repair shop owners who reported that they sell broken clarinets to people who want to use them for decoration or other uses. One repair shop donated pieces of broken clarinets to researchers.

This information about the destinations of broken or abandoned clarinets will contribute to the development of the second part of this report, which is concerned with the measurement of the physical properties of the materials used for clarinet manufacturing (currently prepared for publication).

\section{Information Analysis}

The information collected from the three different sources (literature review, interviews, and online surveys) was processed and combined to provide a list of sustainable alternative wood species to produce clarinets (as listed in Table 12). These species were separated into three categories: $(\mathrm{P})$ species used in the past before the arrival of tropical wood species in Europe; (C) species used currently by manufacturers; and (F) potential wood substitutes for use in the future, as garnered from respondents to this report.

Table 12. List of Species Used to Make Clarinets Found in Literature Reviews, Interviews, and Surveys

\begin{tabular}{|c|c|c|c|c|}
\hline Scientific Name & Common Name & Categories & Origins & Source \\
\hline $\begin{array}{c}\text { Buxus } \\
\text { sempervirens }\end{array}$ & European Boxwood & $P$ & $\begin{array}{c}\text { Southern } \\
\text { Europe, Asia } \\
\text { and North } \\
\text { America }\end{array}$ & (Wegst 2006) \\
\hline Prunus domestica & Plum & $P$ & $\begin{array}{c}\text { Europe to West } \\
\text { Asia }\end{array}$ & (Wegst 2006) \\
\hline Pyrus communis & Pear & $P$ & $\begin{array}{l}\text { Northeastern } \\
\text { United States }\end{array}$ & (Wegst 2006) \\
\hline Acer platanoides & Norway Maple & C & $\begin{array}{l}\text { Northeastern } \\
\text { Europe to } \\
\text { Caucauses }\end{array}$ & (Wegst 2006) \\
\hline $\begin{array}{c}\text { Acer } \\
\text { pseudoplatanus }\end{array}$ & $\begin{array}{c}\text { Sycamore (Curly) } \\
\text { Maple }\end{array}$ & C & $\begin{array}{c}\text { Northwest to } \\
\text { central Europe, } \\
\text { Italy, Western } \\
\text { Asia } \\
\end{array}$ & (Wegst 2006) \\
\hline $\begin{array}{l}\text { Artocarpus } \\
\text { lakoocha }\end{array}$ & Ma-Had & C & Southeast Asia & (Wegst 2006) \\
\hline Byra ebenus & Cocus wood & C & Jamaica, Cuba & $\begin{array}{l}\text { (Hoeprich } \\
\text { 2008) }\end{array}$ \\
\hline $\begin{array}{l}\text { Calycophyllum } \\
\text { multiflorum }\end{array}$ & $\begin{array}{c}\text { Castella Boxwood, } \\
\text { Castelo }\end{array}$ & C & South America & (Wegst 2006) \\
\hline Casearia praecox & $\begin{array}{c}\text { West Indian } \\
\text { Boxwood, Zapatero }\end{array}$ & C & $\begin{array}{c}\text { Central America } \\
\text { to Northern S. } \\
\text { America }\end{array}$ & (Wegst 2006) \\
\hline
\end{tabular}




\begin{tabular}{|c|c|c|c|c|}
\hline $\begin{array}{c}\text { Colophospermum } \\
\text { mopani }\end{array}$ & $\begin{array}{l}\text { Mopane, Mopani, } \\
\text { Mupane, Musharu, } \\
\text { Turpentine tree }\end{array}$ & C & Southern Africa & $\begin{array}{c}\text { (Jousserand } \\
\text { 2015) }\end{array}$ \\
\hline $\begin{array}{l}\text { Dalbergia } \\
\text { cearenses }\end{array}$ & Brazilian Kingwood & C & Brazil & $\begin{array}{c}\text { (Jousserand } \\
\text { 2015) }\end{array}$ \\
\hline $\begin{array}{l}\text { Dalbergia } \\
\text { decipularis }\end{array}$ & Bahia Rosewood & C & Brazil & (Wegst 2006) \\
\hline Dalbergia latifolia & Indian Rosewood & C & $\begin{array}{c}\text { India, Indonesia, } \\
\text { Nepal }\end{array}$ & (Wegst 2006) \\
\hline $\begin{array}{l}\text { Dalbergia } \\
\text { melanoxylon }\end{array}$ & $\begin{array}{c}\text { African Blackwood, } \\
\text { Granadilla, Mpingo, } \\
\text { Pau-Preto, } \\
\text { Mozambique Ebony }\end{array}$ & C & East Africa & $\begin{array}{l}\text { (Hoeprich } \\
\text { 2008) }\end{array}$ \\
\hline Dalbergia nigra & Brazilian Rosewood & C & Brazil & $\begin{array}{l}\text { (Hoeprich } \\
\text { 2008) }\end{array}$ \\
\hline Dalbergia oliveri & Ching-Chan & C & $\begin{array}{c}\text { Myanmar; } \\
\text { Thailand; Viet } \\
\text { Nam } \\
\end{array}$ & (Wegst 2006) \\
\hline Dalbergia retusa & Cocobolo & C & Central America & $\begin{array}{l}\text { (Hoeprich } \\
\text { 2008) }\end{array}$ \\
\hline $\begin{array}{l}\text { Dalbergia } \\
\text { Stevensonii }\end{array}$ & Honduras Rosewood & C & Belize & (Rossi 2015) \\
\hline Dalbergia variabilis & Brazilian Tulipwood & $\mathrm{C}$ & South America & (Wegst 2006) \\
\hline Diospyros celebica & Macassar Ebony & C & Indonesia & (Wegst 2008) \\
\hline $\begin{array}{l}\text { Diospyros } \\
\text { crassiflora }\end{array}$ & $\begin{array}{l}\text { Gaboon Ebony, } \\
\text { African Ebony, } \\
\text { Nigerian Ebony, } \\
\text { Cameroon, Ebony }\end{array}$ & C & Central Africa & Survey \\
\hline $\begin{array}{l}\text { Diospyros } \\
\text { melanoxylon }\end{array}$ & Coromandel, Ebony & C & $\begin{array}{l}\text { India, Nepal, } \\
\text { Pakistan }\end{array}$ & $\begin{array}{l}\text { (Hoeprich } \\
\text { 2008) }\end{array}$ \\
\hline $\begin{array}{l}\text { Guibourtia } \\
\text { schliebenii }\end{array}$ & Red Chacate & C & $\begin{array}{c}\text { Kenya, } \\
\text { Mozambique, } \\
\text { Tanzania }\end{array}$ & (Wegst 2006) \\
\hline $\begin{array}{l}\text { Guibourtia } \\
\text { tessmannii }\end{array}$ & Bubinga & C & Equatorial Africa & (Wegst 2006) \\
\hline Olea europea & Olive & C & Mediterranean & (Wegst 2006) \\
\hline
\end{tabular}




\begin{tabular}{|c|c|c|c|c|}
\hline $\begin{array}{c}\text { Stephegyne } \\
\text { parviflora }\end{array}$ & Indian Kamba & C & $\begin{array}{c}\text { India, Pakistan } \\
\text { and Sri Lanka }\end{array}$ & (Wegst 2006) \\
\hline $\begin{array}{c}\text { Handroanthus } \\
\text { impetiginosus }\end{array}$ & $\begin{array}{c}\text { Purple Trumpet Tree, } \\
\text { Purple Ipe, Purple } \\
\text { Lapacho, Pau D'arco }\end{array}$ & F & $\begin{array}{c}\text { Argentina, } \\
\text { Brazil, Costa } \\
\text { Rica, Mexico }\end{array}$ & $\begin{array}{c}\text { (Jousserand } \\
\text { 2015) }\end{array}$ \\
\hline $\begin{array}{c}\text { Handroanthus } \\
\text { serratifolius }\end{array}$ & $\begin{array}{c}\text { Yellow Trumpet Tree, } \\
\text { Yellow Poui, Yellow } \\
\text { Ipe }\end{array}$ & F & $\begin{array}{c}\text { Central America } \\
\text { to South } \\
\text { America }\end{array}$ & $\begin{array}{c}\text { (Jousserand } \\
\text { 2015) }\end{array}$ \\
\hline Note: P = Species used in the past; C = Species used currently; F = Possible Species for the \\
future;
\end{tabular}

According to the list of species used in clarinet production, which was created from various sources for this study, very few wood species are considered suitable for the manufacturing of woodwind instruments. Such species must have a flawless and evengrained wood and be capable of being worked to extremely fine tolerances (Jenkins et al. 2002). African Blackwood is the most used species for clarinet production because the characteristics of this species meets the all the criteria for clarinet manufacturing better than any known alternative species. These characteristics include high density, closegrained nature, natural oiliness, fine texture, high durability and black color. For this reason, clarinet manufacturers consider this species to be superior for clarinet production (Slooten and Souza 1993; Jenkins et al. 2002). The manufacturing of other instruments from African Blackwood is evidently on a much smaller scale. Other species used in clarinet production share some of these characteristics (most commonly high density and high durability) but fall short in other respects.

However, the intense exploitation of African Blackwood for musical instruments since 1970 increases the potential risk of extinction of this species (Jenkins et al. 2002). As such, African Blackwood has been considered an endangered species, categorized as "Near threatened (NT)" by the International Union for Conservation of Nature's Red List of Threatened Species, IUCN Red list, (Barstow 2020). This is an organization that classify species at high risk of global extinction. These categories are shown in Fig. 3.

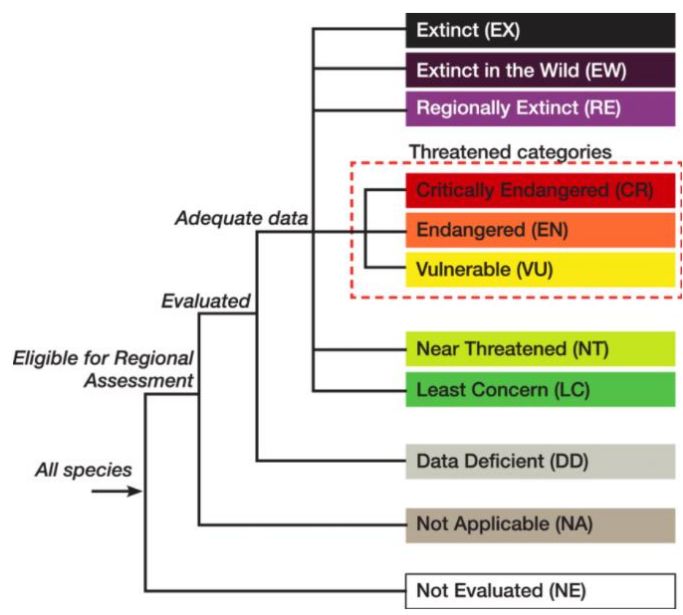

Fig. 3. Structure of the categories used at the regional level (IUCN 2012) 
The levels of exploitation of African Blackwood are very high; for this reason, individual trees are becoming increasingly rare. This causes the concern of genetic erosion (lost genetic diversity) in several populations. According to Barstow (2020), African Blackwood is experiencing a population decline in many countries of Africa, due primarily to international demand to produce musical instruments, but also due to the production of traditional 'hongmu' furniture in China. In addition, other factors causing this population decline include habitat loss and degradation. As reported by Barstow (2020), "Over the last 150 years it is suspected that population decline is between $20 \%$ and $30 \%$. (...) The [tree] population decline is ongoing and, moving into the future, decline is suspected to be equivalent ( $20 \%$ to $30 \%$ decline over the next one hundred years)". Apart from the existence of national legislation and forestry policy to reduce the over-exploitation of the species, it is also necessary to use alternative species to produce clarinets, and consequently, decrease the pressure on this limited resource.

Therefore, with the objective of finding viable alternative species for clarinet production, the key properties of African Blackwood were compared to other species (table 13). These properties are high density, exceptional durability, fine texture, straight grain, and the black color of the wood. These are important characteristics to determine the clarinet's acoustic, except color, which is a valued property only for aesthetic quality. The potential alternative species were classified into five classes, being $\mathrm{A}$ the best one and $\mathrm{E}$ the worst one, for clarinet manufacturing. Class A has all characteristics similar to African Blackwood, class B has 4 similar characteristics, class C, 3, class D, 2, and class E presents only 1 similar property. Visual color determination is a subjective and delicate enterprise. To evaluate color similarities, this property was divided in 2 classes: dark and light colors. The wood colors of species from table below fall in a relatively small range between light yellow and dark brown, with some species that are black, which is the preferred color for clarinet production. These species were also classified by IUCN Red List.

Table 13. Classification of Possible Alternative Species for Clarinet Production

\begin{tabular}{|c|c|c|c|c|c|c|c|}
\hline Scientific Name & Heartwood Color & Grain & Texture & Density & Durability & Class & $\begin{array}{l}\text { Red } \\
\text { List }\end{array}$ \\
\hline $\begin{array}{c}\text { Dalbergia } \\
\text { melanoxylon }\end{array}$ & Black $^{a}$ & Straighta & $\underline{\text { Fine }^{a}}$ & $\underline{\text { Higha }^{\prime}}$ & $\underline{\text { Higha }}$ & & NT \\
\hline $\begin{array}{c}\text { Diospyros } \\
\text { melanoxylon }\end{array}$ & Blacke & Straighte & $\underline{\text { Fine }}$ & $\underline{\text { Highe }}$ & $\underline{\text { Highe }}$ & A & NE \\
\hline $\begin{array}{l}\text { Handroanthus } \\
\text { serratifolius }\end{array}$ & Dark brown $^{f}$ & Straight $f$ & $\underline{\text { Fine }^{f}}$ & $\underline{\text { Highf }^{\prime}}$ & $\underline{\text { Highf }}$ & A & $\mathrm{NE}$ \\
\hline $\begin{array}{c}\text { Colophospermum } \\
\text { mopane }\end{array}$ & $\frac{\text { Dark reddish }}{\underline{\text { brown }^{a}}}$ & $\begin{array}{c}\text { Interlocked } \\
\text { a } \\
\end{array}$ & $\underline{\text { Fine }^{a}}$ & $\underline{\text { Higha }^{a}}$ & $\underline{\text { Higha }^{a}}$ & $B$ & LC \\
\hline $\begin{array}{l}\text { Dalbergia } \\
\text { cearensis }\end{array}$ & $\begin{array}{l}\text { Dark purplish or } \\
\text { reddish browna } \\
\end{array}$ & $\begin{array}{c}\text { Straight to } \\
\text { interlockeda }^{2}\end{array}$ & $\underline{\text { Fine }^{a}}$ & $\underline{\text { Higha }^{a}}$ & $\underline{\text { Higha }}$ & $B$ & NE \\
\hline Dalbergia nigra & $\begin{array}{l}\frac{\text { Darker chocolate }}{\text { brown to a }} \\
\frac{\text { lighter purplish }}{\frac{\text { or reddish }}{\text { browna }}}\end{array}$ & $\underline{\text { Straighta }}$ & $\begin{array}{l}\text { Medium } \\
\text { to } \\
\text { coarse }\end{array}$ & $\underline{\text { Highd }}$ & $\underline{\text { Higha }}$ & B & VU \\
\hline $\begin{array}{l}\text { Diospyros } \\
\text { crassiflora }\end{array}$ & Black $^{a}$ & $\begin{array}{c}\text { Straight to } \\
\text { interlockeda }\end{array}$ & $\underline{\text { Fine }^{a}}$ & $\underline{\text { Higha }^{a}}$ & $\underline{\text { Higha }^{a}}$ & B & VU \\
\hline
\end{tabular}




\begin{tabular}{|c|c|c|c|c|c|c|c|}
\hline $\begin{array}{l}\text { Handroanthus } \\
\text { impetiginosus }\end{array}$ & Brownish brownd & Straightd & $\begin{array}{l}\text { Fine to } \\
\text { medium }\end{array}$ & $\underline{\text { Highd }}$ & $\underline{\text { Highd }}$ & B & $\mathrm{LC}$ \\
\hline Acer platanoides & $\frac{\text { Darker reddish }}{\text { brown }^{a}}$ & $\underline{\text { Straighta }}$ & $\underline{\text { Fine }^{a}}$ & $\begin{array}{c}\text { Mediu } \\
\mathrm{m}^{\mathrm{b}}\end{array}$ & Lowa & C & LC \\
\hline Byra ebenus & Reddish browna & $\begin{array}{l}\text { Straight to } \\
\text { wavya }\end{array}$ & $\underline{\text { Fine }^{a}}$ & $\underline{\text { Higha }^{a}}$ & $\underline{\text { Higha }^{a}}$ & C & NE \\
\hline Casearia praecox & Light yellowc & Straightc & Finec & $\underline{\text { Highc }}$ & Lowc & C & LC \\
\hline $\begin{array}{c}\text { Dalbergia } \\
\text { decipularis }\end{array}$ & Yellow to reda & Straighta & $\underline{\text { Fine }^{a}}$ & $\underline{\text { Higha }^{a}}$ & Lowa & C & LC \\
\hline Dalbergia oliveri & $\begin{array}{l}\frac{\text { Medium orange }}{\text { to a darker }} \\
\text { reddish browna }\end{array}$ & $\begin{array}{c}\text { Straight to } \\
\text { interlockeda }\end{array}$ & $\begin{array}{l}\text { Fine to } \\
\text { mediuma }\end{array}$ & $\underline{\text { Highb }^{b}}$ & $\underline{\text { Higha }}$ & C & EN \\
\hline Dalbergia retusa & $\begin{array}{l}\text { Ranging from } \\
\text { yellow, orange, } \\
\text { red, and shades of } \\
\text { browna }\end{array}$ & $\begin{array}{c}\text { Straight to } \\
\text { interlockeda }\end{array}$ & $\underline{\text { Fine }^{a}}$ & $\underline{\text { Higha }^{a}}$ & $\underline{\text { Higha }}$ & C & CR \\
\hline $\begin{array}{l}\text { Dalbergia } \\
\text { variabilis }\end{array}$ & $\begin{array}{l}\text { Ranging from } \\
\text { yellow, orange, } \\
\text { red, and pinka }\end{array}$ & Straighta & $\underline{\text { Fine }^{a}}$ & $\underline{\text { Higha }}$ & Lowa & C & NE \\
\hline $\begin{array}{l}\text { Diospyros } \\
\text { celebica }\end{array}$ & $\begin{array}{c}\text { Yellow to reddish } \\
\text { browna }\end{array}$ & $\begin{array}{c}\text { Straight to } \\
\text { interlocked }\end{array}$ & $\underline{\text { Fine }^{a}}$ & $\underline{\text { Higha }}$ & $\underline{\text { Higha }}$ & C & VU \\
\hline $\begin{array}{c}\text { Acer } \\
\text { pseudoplatanus }\end{array}$ & $\frac{\text { Darker reddish }}{\text { brown }^{\mathrm{a}}}$ & $\begin{array}{c}\text { Straight to } \\
\text { wavya }\end{array}$ & $\underline{\text { Fine }^{a}}$ & $\begin{array}{c}\text { Mediu } \\
\mathrm{m}^{\mathrm{b}}\end{array}$ & Lowa & $\mathrm{D}$ & LC \\
\hline $\begin{array}{c}\text { Buxus } \\
\text { sempervirens } \\
\end{array}$ & $\begin{array}{l}\text { Light cream to } \\
\text { yellowa }\end{array}$ & Straighta & $\underline{\text { Fine }^{a}}$ & $\begin{array}{c}\text { Mediu } \\
\mathrm{m}^{\mathrm{b}}\end{array}$ & Mediuma & $\mathrm{D}$ & LC \\
\hline Dalbergia latifolia & $\begin{array}{l}\text { Golden brown to } \\
\text { purplish browna }\end{array}$ & $\begin{array}{c}\text { Interlocked } \\
\text { a }\end{array}$ & Mediuma $^{a}$ & $\underline{\text { Higha }}$ & $\underline{\text { Higha }}$ & $\mathrm{D}$ & VU \\
\hline $\begin{array}{l}\text { Guibourtia } \\
\text { tessmannii }\end{array}$ & $\frac{\text { Pinkish red to a }}{\frac{\text { darker reddish }}{\underline{\text { brown }^{a}}}}$ & $\begin{array}{c}\text { Straight to } \\
\text { interlockeda }\end{array}$ & $\begin{array}{l}\text { Fine to } \\
\text { mediuma }\end{array}$ & $\underline{\text { Higha }}$ & $\begin{array}{l}\text { Medium } \\
\text { to Higha }\end{array}$ & $\mathrm{D}$ & EN \\
\hline Olea europaea & $\begin{array}{c}\text { Cream or } \\
\text { yellowish browna }\end{array}$ & $\begin{array}{c}\text { Straight to } \\
\text { interlockeda }\end{array}$ & $\underline{\text { Fine }^{a}}$ & $\underline{\text { Highe }}$ & Lowa & $\mathrm{D}$ & NE \\
\hline Pyrus communis & $\begin{array}{l}\text { Pink to light } \\
\text { reddish brown }\end{array}$ & Straighta & $\underline{\text { Fine }^{a}}$ & $\begin{array}{c}\text { Mediu } \\
\mathrm{m}^{\mathrm{b}}\end{array}$ & Lowa $^{a}$ & $\mathrm{D}$ & LC \\
\hline $\begin{array}{c}\text { Calycophyllum } \\
\text { multiflorum }\end{array}$ & $\begin{array}{l}\text { Light brown to } \\
\text { pale yellowisha }\end{array}$ & $\begin{array}{c}\begin{array}{c}\text { Straight to } \\
\text { interlocked a }\end{array} \\
\end{array}$ & $\underline{\text { Fine }^{a}}$ & $\begin{array}{c}\text { Mediu } \\
\mathrm{m}^{\mathrm{b}}\end{array}$ & Mediuma & $E$ & NE \\
\hline $\begin{array}{l}\text { Dalbergia } \\
\text { stevensonii }\end{array}$ & $\begin{array}{c}\text { Brownish-purple to } \\
\text { a light-browna }\end{array}$ & \begin{tabular}{|c|}
$\begin{array}{c}\text { Straight to } \\
\text { interlocked }\end{array}$ \\
\end{tabular} & $\begin{array}{c}\text { Fine to } \\
\text { medium }\end{array}$ & $\begin{array}{c}\text { Mediu } \\
\mathrm{m}^{\mathrm{b}}\end{array}$ & $\underline{\text { Higha }^{a}}$ & $E$ & NE \\
\hline \multicolumn{8}{|c|}{$\begin{array}{l}\text { Source: a(Meier 2021), b(Harja et al. 2021), c(Record and George 1925), d(Mainieri and Chimelo 1989), } \\
\text { e(Zadro 1975), f(Teles and Souza 2005) }\end{array}$} \\
\hline \multicolumn{8}{|c|}{$\begin{array}{l}\text { IUCN Red list categories: NE = Not evaluated; LC = Least Concern; NT = Lower Risk/near threatened; } \\
\text { EN = Endangered; VU = Vulnerable; CR = Critically endangered; } \\
\text { Legend: Bold: Similar characteristics, Not bold: Different characteristics }\end{array}$} \\
\hline \multicolumn{8}{|c|}{$\begin{array}{l}\text { Note: Classes represent the number of properties similar to African Blackwood: } \mathrm{A}=5 ; \mathrm{B}=4 ; \mathrm{C}=3 ; \mathrm{D}= \\
2, \mathrm{E}=1 . \\
\text { Some species from table } 12 \text { was not included in table } 13 \text { due to insufficiency of data, such as: } \\
\text { Artocarpus lakoocha, Prunus domestica, Guibourtia schliebenii, Stephegyne parviflora }\end{array}$} \\
\hline
\end{tabular}


From the list of species presented above (Table 13), Diospyros melanoxylon and Handroanthus serratifolius are the most favorable for clarinet manufacturing, since they have the greatest number of similarities with African Blackwood: high density and durability, fine texture, straight grain, and dark colors. Therefore, these two species were classified in class A. From 23 species, only 5 species were categorized in class B as they match 4 characteristics and differ in only 1 characteristic from African Blackwood. Dalbergia cearensis, Diospyros crassiflora, Colophospermum mopane have high durability and density, fine texture and dark color but not a straight grain, differing in this aspect from African Blackwood. Although Dalbergia nigra and Handroanthus impetiginosus have high durability and density, dark color, and straight grain, they also differ from African Blackwood in the texture property. Most species from this list fall into class C, having 3 similar properties with African Blackwood. Another 6 species were classified into class D because they present 2 similar characteristics. Finally, Class E has only 2 species that have 1 similar and 4 different characteristics compared to African Blackwood.

Nevertheless, the acoustical quality of a species is not the only matter for the clarinet industry; the extinction threat due exploitation is also a concern. From the list of alternative species for clarinet manufacturing, 16 species were classified into different categories from the IUCN Red list, and 6 were not evaluated (NE). Even though class A and B have 7 species that have 4 or 5 characteristics similar to African Blackwood, only 3 were not evaluated - NE by IUCN Red List, implying that these species are not endangered and, therefore, can be considered potential alternative species to produce high quality clarinets. They are Diospyros melanoxylon, Handroanthus serratifolius and Dalbergia cearensis. Another 2 species were classified as "Least Concern (LC)", and other 2 species as "Vulnerable (VU)", consequently, they cannot be considered as potential alternative species to produce clarinets since they are being exploited for other uses.

Therefore, further studies are needed to test the physical properties of African Blackwood and use these properties as a key for testing and matching the potential alternatives. This data, rather than the opinions expressed by the community, may convince manufacturers to change. The empirical study is the topic of the second part of this research.

One problem faced in this research is that the information about alternative species was often in its common name or a group of species and not the scientific name of a specific species, making species identification by popular name difficult, but necessary, to create the list of alternative species for clarinet production.

\section{CONCLUSIONS}

1. Results suggest that the material used in clarinet production contributes to the musical quality of the instrument, so the physical properties of the wood species are crucially relevant to the quality of the instrument. Then, potential alternative wood species for clarinet production have the following characteristics: high density, fine texture, exceptional durability, black appearance of the wood, natural oiliness, dimensional stability, impermeability to air, strength sufficient for supporting the weight of the keywork, resistance to climate change, and the ability to achieve an exceptional finish quality. 
2. Therefore, it is suggested that similarities in the key properties of density, durability, grain, texture, and color, can help in selecting the wood best suited for the manufacture of high-quality clarinets similar to the reference African Blackwood wood. Based on this study, Diospyros melanoxylon, Handroanthus serratifolius, and Dalbergia cearensis are potential alternative wood species for clarinet manufacturing, since these species have the greatest number of similarities and are not endangered.

3. Most of the respondents from the survey cited a species that was already known. This shows the traditional use of this species and possibly suggests some difficulty in introducing new species to the market with characteristics different from the traditionally used species.

\section{ACKNOWLEDGEMENTS}

The authors thank all people consulted and who generously provided information for the study, as well as Gracewinds Music in Corvallis, Oregon for generous donations of broken clarinets, Buffet Crampon, clarinet manufacturer in France, for the generous donations of wood pieces for study, the Brazil Scientific Mobility Program, IIE and CAPES, Oregon State University, Corvallis, OR, and the Forestry Institute, Brazil.

\section{REFERENCES CITED}

African Blackwood Conservation Project (2018). "Dalbergia melanoxylon in woodwind instruments," (https://www.blackwoodconservation.org/woodwind-instruments/), Accessed 02 March 2018.

Ball, S. M. J. (2004). "Stocks and exploitation of East African blackwood Dalbergia melanoxylon: A flagship species for Tanzania's miombo woodlands?” Oryx 38(3), 266-272. DOI: 10.1017/S0030605304000493

Barstow, M. (2020). "Dalbergia melanoxylon. The IUCN red list of threatened species 2020,” (https://www.iucnredlist.org/species/32504/67798379), Accessed 15 March 2021.

Gregory, A. M., Ball, S. M. J., and Eziefula, U. E. (1999). Tanzanian Mpingo 98 Full Report, Fauna and Flora International, Cambridge, United Kingdom.

Harja, D., Rahayu, S., Pambudi, S. (2021). "Tree functional attributes and ecological database," (http://db.worldagroforestry.org/), Accessed 17 June 2021.

Harrison, P. (2008). "A summary of the supply chain for African Blackwood, market economics and opportunities for community forest certification," Environment Africa Trust, Nantwich, UK.

Hascoet, S. (2020). "Dalbergia melanoxylon in woodwind instruments," (https://www.blackwoodconservation.org/woodwind-instruments), Accessed 04 May 2020.

Hoeprich, E. (2008). The Clarinet, Yale University Press, The Yale Music Instrument Series, New Haven, United Kingdom.

IUCN (2012). Red List of Threatened Species. Guidelines for Application of IUCN Red List Criteria at Regional and National Levels: Version 4.0, IUCN Species Survival Commission, Gland, Switzerland. 
Jenkins, M., Oldfield, S., Aylett, T. (2002). International Trade in African Blackwood Fauna and Flora International, Cambridge, UK.

Jousserand, M. (2015). Interview with Michael Jousserand - Research Engineer - Buffet group (BARROS, L.C.A., Interviewer).

Kenyon, G. (2011). "National tree of Tanzania makes sustainable music," (https://www.fauna-flora.org/news/national-tree-of-tanzania-makes-sustainablemusic), Accessed 23 June 2020.

Lincoln, W. A. (1986). World Woods in Color, Linden Publishing, London, UK.

Mainieri, C., and Chimelo, J. P. (1989). Fichas de Características das Madeiras Brasileiras, IPT (Instituto de Pesquisas Tecnológicas), São Paulo, Brazil.

Meier, E. (2021). “The wood database," (http://www.wood-database.com/), Accessed 17 June 2021.

Nakai, K. (2020). Enhancing the Potential of African Blackwood, Dalbergia melanoxylon, through Sustainable Forest Utilization: A Valuable Tree Species in Tanzanian Miombo Gorest, Master's Thesis, Kyoto University, Kyoto, Japan.

Nakai, K., Ishizuka, M., Ohta, S., Timothy, J., Jasper, M., Lyatura, N. M., Shau, V., and Yoshimura, T. (2019). "Environmental factors and wood qualities of African blackwood, Dalbergia melanoxylon, in Tanzanian Miombo natural forest," J. Wood Sci. 65(39), 1-11. DOI: 10.1186/s10086-019-1818-0

Nakai, K., and Yoshimura, T. (2020). "African blackwood (Dalbergia melanoxylon) and other local Tanzanian tree species' biological performance against subterranean termites and wood decay fungi," BioResources 15(2), 2994-3005.

Palmer, K. (2015). Interview with Katherine Palmer - Museum educator - MIM, Musical Instruments Museum (BARROS, L.C.A., Interviewer).

Palmer, K. (2016). "Place-based education, the third sector, and community music: Merging music and conservation education in Tanzania," in: Proceedings of the XV International Seminar of the ISME Commission on Community Music Activity, Edinburgh College, Edinburgh, Scotland, pp. 111-116.

Perry, N. (2008). "Tanzania tree strikes right note," (http://news.bbc.co.uk/2/hi/africa/7388088.stm), Accessed 02 June 2020.

Record, S. J., and George A. G. (1925). "Boxwoods," Yale School of Forestry \& Environmental Studies, Bulletin Series 14.81 pp.

Ranker (2018). "The best clarinet brands," (https://www.ranker.com/list/best-clarinetbrands/ranker-shopping), Accessed 20 April 2021.

Rossi, L. (2015). Interview with Luis Rossi Owner - Hand Made Clarinets (Barros, L. C. A., Interviewer).

Slooten, H. J. V. d., and Souza, M. R. d. (1993). “Avaliação das espécies madeireiras da Amazônia selecionadas para a manufatura de instrumentos musicais [Evaluation of Amazonian timber species selected for the manufacture of musical instruments]," Instituto Nacional de Pesquisas da Amazônia, Manaus, Brazil.

Teles, R. F., and Souza, M. R. (2005). Avaliação de Madeira Amazônica para Utilização em Instrumentos Musicais [Evaluation of Amazon Wood for use in Musical Instruments], Master's Thesis, Universidade de Brasilia, Brasilia, Brazil.

Wegst, U. G. K. (2006). "Wood for sound," American Journal of Botany 93(10), 14391448. DOI: 10.3732/ajb.93.10.1439

Wegst, U. G. K. (2008). "Bamboo and Awood in musical instruments," Annual Review of Materials Research 38, 323-349. DOI: 10.1146/annurev.matsci.38.060407.132459 
Zadro, M. G. (1975). Woods Used for Woodwind Since the $16^{\text {th }}$ Century 2: A Descriptive Dictionary of the Principal Woods Mentioned, Oxford University Press, 3(3), 249251.

Article submitted: March 23, 2021; Peer review completed: May 16, 2021; Revised version received and accepted: July 24, 2021; Published: July 28, 2021.

DOI: $10.15376 /$ biores.16.3.6292-6312 